Mainstream Accounting and Its Paradigm: A Critical

Analysis (Imam Wahyudi): 99-112

\title{
MAINSTREAM ACCOUNTING AND ITS PARADIGM: A CRITICAL ANALYSIS
}

\section{Imam Wahyudi}

This paper discusses the methodology dominantly used in accounting research, namely, mainstream accounting research methodology. This methodology which relies on the methodology of natural sciences and is called hypothetico-deductive approach assumes that human beings are passive objects and has no power to create social realities. As a result, accounting tends to be seen as an objective information separated from its social environment.

This belief has created many disadvantages to the development of accounting practices and accounting research itself. Accounting research tends to be separated from accounting practices. Consequently, a lot of research findings cannot be applied in accounting practice. Thus, accounting research and accounting theorizing may not produce a real answer to the accounting problems.

Keywords: accounting research; hypothetico-deductive approach; mainstream accounting

\section{Introduction}

Accounting research as reflected in the mainstream accounting journals has been inclined to concentrate on the functionalist paradigm which is derived from the natural sciences. This paradigm views accounting phenomena as concrete realworld relations possessing regularities and causal relationships that are ame- nable to scientific explanation and prediction (Belkaoui 1987:61).

However, this paradigm has come to be seen as increasingly unsatisfactory as a basis for social research. It is only producing a scientific imitation by adopting a policy of measuring, observing, experimenting, collecting data which can play an important part but are not characteristics of natural sciences (Wisdom 1987). 


\section{Assumptions About the Nature of Science}

A paradigm is formed from two sets of assumptions. The first set is assumptions about the nature of social sciences consisting of ontological, human nature, epistemological, and methodological assumptions. The second set is assumptions about the nature of society or the social world.

\section{Ontological and Human Nature Assumptions}

As a consequence of its adoption to the natural scientific research methodology, mainstream accounting research is developed by assumptions similar to those used in the natural science. Ontologically, mainstream accounting research is dominated by a belief in physical realism which is closely related to the distinction of the subject and the object often made. The object is presumed to be independent of the subject and knowledge is achieved when a subject correctlymirrors and "discovers" this objective reality (Chua 1986: 606).

Hence, the reality exists concretely and independently of the social actors and social practices (Tinker et al. 1982). Individuals are seen as passive persons who do not construct the reality but they are simply analyzed as entities that are passively described in objective ways. In other words, a human is seen as a passive receptor of discrete, atomic impressions from the outside (Steffy and Grimes 1986).

Within this view, economic reality is treated as having an independent existence from accounting practices. The role of accounting is merely to communicate the reality so that it is treated as a passive instrument of technical administration and a neutral mean for revealing the granted aspects of organizational functioning (Solomons 1991; Hines 1989; Hopwood 1987). Moreover, accounting is value-free of any particular goal and the value placed upon that goal (Chua 1986).

In detail, the ontological assumptions of the functionalist paradigm can be distinguished into three categories from the extremely objective to the least objective. These are 1) reality as a concrete structure, 2) reality as a concrete process, and 3 ) reality as a contextual field of information (Covaleski and Dirsmith 1990; Tomkins and Groves 1983; Morgan and Smircich 1980).

The first category which sees reality as a concrete structure is the most extreme of objective approaches to social science. It views the social world as a network of determinate relationships as the world of physics and chemistry. By appropriate observation and measurement scales, it is assumed that one has, readily available, stable, and usually very simple, functions relating to isolated and small subsets of the social world which can be used for accurate predictions (Tomkins and Groves 1983).

Consistent with this assumption, human beings are seen as responding mechanism that are a product of the external forces in the environment they are exposed (Morgan and Smircich 1980). Causal relationship networks link all important aspects of human behavior since they are assumed to behave and respond to events in predictable and determinate ways. The majority of accounting research and theorizing can be placed within this view which believes in a social world as concrete and as real as the natural world (Belkaoui 1987; Hopper and Powell 1985; Tomkins and Groves 1983).

The second category relaxes the assumption by saying that reality is a con- 
crete process which means concrete in nature but ever-changing in detailed form (Morgan and Smircich 1983). Determinate causal relationships between constituent processes are difficult to find since everything interacts with everything else. However, there are some general and contingent relationships which are stable and can be used for prediction to find out the general patterns of change.

As mentioned by Morgan and Smircich (1980), human beings are seen as adaptive agents that exist in an interactive relationship with their world. Compared to the first category, there are shifts from mechanical to organic analogies, and from closed to open systems. It is reflected in the accounting research in the form of accounting dysfunction that can be seen in open systems theory (see, for example: Anshari 1977), contingency theory (see, for example: Waterhouse and Tiessen 1978; Tiessen and Waterhouse 1983; Otley 1980), budgetary styles (see, for example: Hopwood 1972; Otley 1978; Brownell 1981).

Third category that sees reality as a contextual field of information is less objective within the functionalist paradigm compared to the first and second categories. Human beings are assumed to be continually processing information, learning and adapting. The adaptation process may for long periods be harmonious and predictable, but it may also from time to time be unstable (Tomkins and Groves 1983:368). The main intention is to indicate the likelihood that disturbances in one part of an organization will bring about changes elsewhere.

Accounting research in this area, according to Tomkins and Groves (1983), attempts to provide a large model of interconnections and relationships between objects being examined and their environ- ment. If the models are well developed, they can be used to simulate on a probabilistic basis the behavior of internal and external relationships (Morgan and Smircich 1980). Cybernetic research approaches are usually used and are appropriate to such a worldly view.

Pluralism can also be classified under this category. These approaches view organizations not as tools but as a network of inter-related, politically-motivated, conflicting groups (Dermer 1988:30). The aim is to eliminate conflict by negotiating courses of actions which permiteach group maximumfreedom consistent with the binding constraints laid down by other groups (Hopper and Powell 1985:443). In accounting research, the pluralistic studies suggest that accounting rules may come from sectional interests and are mediated through political processes. The work of Burchell et al. (1980) which shows that accounting data often emerged from political processes rather than preceding them, is an example.

The main thesis of Burchell et al. was to emphasize that accounting information served to reduce perceived uncertainty and to abate and objectify anxiety (Mason 1980 as quoted in Hopper and Powell 1985). The fact is that pluralism tends to use research strategies such as case studies, field studies, and process-tracing studies to get more informed basis for model, hypothesis-formation activities, testing of validity and generating objective theories (Kaplan 1986; Yin 1984; Abdel-Khalik and Ajinkya 1983).

Thus, consistent with the functionalist paradigm, the pluralistic approaches still believe that social protagonists share a common interest in sustaining the whole system and neutrality is pursued as a mediating role in conflict resolution (Tinker et al. 1991). This means that pluralism 
presumes purposeful and self-interest behavior arising from a realist ontology where socially created accounting is recognized in terms of manipulative action to seek external legitimating and to mask underlying realities (Hopper and Powell 1985).

\section{Epistemological and Methodological Assumptions}

These three ontological assumptions above have different epistemological implications. The epistemology of an extreme positivism that emphasizes an empirical analysis of concrete structural relationships, is a reflection of the first category of the ontological assumption, while the second category gives way to an epistemology emphasizing the need to understand processes of organism change (Morgan and Smircich 1980; Tomkins and Groves 1983; Covaleski and Dirsmith 1990). In fact, the second category is similar to the first category in terms of using quantitative measures or standard qualitative classifications in searching for generalized patterns of change.

The third category of the ontological assumption is the causes of the epistemology concerned with the mapping of the contexts and facilitating understanding of the pattern of systemic relationships inherent in the ecological nature of those contexts (Morgan and Smircich 1980). As far as research in accounting is concerned, the contextual approach might attempt to draw a large model showing the interconnections between the environment and parts of an organization being examined (Tomkin and Groves 1983:368). This focus might provide a richer empirical basis in reflecting factors that might be implicated in accounting change and the processes through which this takes place (Hopwood 1983).
In principle, they share the same epistemological assumption, namely positivism, which is characterized by the tenets of unity of science or scientific method and empiricism (Stockman 1983). In accordance with this notion, there is a distinction and separation between observations and theoretical constructs. Related to this case, Chua (1986) states that a world of observation is separated from the theory and the former may be used to attest to the scientific validity of the latter.

It is supported by Abdel-Khalik and Ajinkya (1983) who state that there are three principal determinants of the choice of research methods within the scientific methodology of research. First is the degree of phenomena that can or cannot be simulated in artificial settings. Second is the degree to which overt control or observation can bias the social relevant reality. Finally is the availability of a prior theory. For example, in the case where the phenomenon cannot be simulated in an artificial setting, the prior theory is available and the phenomenon can be affected or biased by explicit control, manipulation or observation, a research needs to be conducted in the real phenomenon by using research strategies such as quasi-experiment, field and case study, or unstructured interview.

The positivism which is directed to explain and predict social phenomenon by searching for regularities and causal relationships between its constituent elements has been expressed in two ways. Those ways are verificationism and falsificationism (Chua 1986; Burrell and Morgan 1979; Christenson 1983; Richards 1983). However, both accept a cumulative process in progress of knowledge by which new insight are added to the existing stock of knowledge and false hypothesis eliminated (Burrell and Morgan 1979). 
The verificationists claims that the only meaningful propositions are those either of logic and mathematics or of empirical science. The scientific propositions are meaningful if these can be verified by observation in an adequate experimental research program (Richards 1983). Under the verificationism, empirical science is viewed as a product or a body of systematized knowledge (Christenson 1983).

On the other hand, falsificationism views the empirical science as a process of human activity producing the knowledge (Christenson 1983). This notion asserts that to be scientific, a proposition must be logically able to be falsified. Furthermore, a proposition can be falsified if there is at least one observational proposition by which it is logically inconsistent. The strength of a proposition is a measure of its generality, for a more general proposition is bound to offer more opportunities for falsification than a more limited one that it subsumes (Richards 1983:55). Hence, the acceptance of a proposition in the body of knowledge is always tentative.

There is no doubt that positive accounting theorists believe in the empirical testability of scientific theories (Christenson 1983; Sterling 1990; AbdelKhalik and Ajinkya 1979; Watts and Zimmermann 1990). Unfortunately, according to Chua (1986), they draw on both notions of verificationism and falsificationism without considering the criticism of both criteria and their differences. It can be seen that even among scientific theorists themselves, there are differences in viewing objective reality (Casti 1989).

The epistemology of positivism has brought to the consequence that the mainstream accounting tends to lay emphasis on the nomothetic methodology which relies upon systematic protocol and tech- nique of research (Burrell and Morgan 1979). It is epitomized in the approach and methods employed in the natural sciences in the form of hypothetico-deductive approach of what constitutes a scientific explanation (Chua 1986; Gaffikin 1984).

To be considered scientific, an explanation should fulfill three components. First, it must incorporate one or more general principles or scientific laws that will state truly invariable relations and regularities (Richards 1983). The second is the existence of prior condition in the form of an observational statement. And finally, a statement describes whatever is being explained. The explanation shows that the event to be explained follows from the general principles, given that the prior condition also holds (Chua 1986).

This model of scientific explanation is widely accepted in accounting research. Abdel-Khalik and Ajinkya (1979) describe that to be scientific, accounting research must be conducted within empiricism. They identify eight steps of an effective research. These include research problem identification, development of the conceptual and theoretical structure, theoretical constructs and relationship operation and statement of the hypothesis to be tested, research design construction, sampling and data gathering, hypothesis testing by observational analysis, evaluation of the results, and disclosure of limitations and constraints.

The model has influenced the widespread use of true and laboratory experiments, survey methods by using large samples and most observation methods. All of these characterize most research in accounting, such as contingency approach in management accounting, the positive theory of accounting, transaction cost theory and the efficient capital market research. Consistent with the hypothetico- 
deductive approach, the common assumption is a search for universal regularities and causal relationships.

Consequently, soft methods of research such as case studies and field studies are relatively neglected because these methods are not statistically valid and even though these are appropriate for generating hypotheses, the methods cannot be used to test them (Hagg and Hedlund 1979). Functionalism usually represents prejudices against case studies by arguing that these studies are inconclusive and equivocal in their results, sloppy and provide little basis for scientific generalization, and have a tendency to become massive unreadable documents full of narrative detail but lacking in theoretical direction (Yin 1984).

However, within the functionalist paradigm itself, a tendency to study accounting in its real environment has emerged. It can be seen in the efforts to introduce soft methods of research such as case studies and field studies by many researchers (see, for examples: AbdelKhalik and Ajinkya 1983; Hagg and Hedlund 1979; Smith et al. 1988; Kaplan 1986). Accordingly, the discussion is usually focused on how to make generalization of the results of these methods possible.

Yin (1984:24-25) points out that case studies should not be confused with the burgeoning use of qualitative research. $\mathrm{He}$ asserts that case studies can be based entirely on quantitative evidence, besides this need not always include direct and detailed observations as a source of evidence. Furthermore, he identifies six sources of evidence that can be used in the case studies. These are documentation, archival records, interviews, direct observation, participant-observation, and physical artifacts. It is believed that exercising these six sources can help to overcome the problems of reliability and validity of case studies.

This is in accordance with Eisenhardt (1989) who suggests that case studies enable the use of multiple data collection methods and combination of quantitative and qualitative data. To generalize the result, cross-case pattern search using divergent techniques can be exercised in data analysis (Eisenhardt 1989; Yin 1984). In general, the case studies can be used to explain the causal links in real-life interventions that are too complex for the survey or experimental strategies (Yin 1984:25).

Also, Abdel-Khalik and Ajinkya (1983) state that the interpretive paradigm can be exercised in combination with the scientific approach or functionalist paradigm to study accounting in its real environment. Under the condition where a phenomenon cannot be simulated in an artificial setting, a prior theory is available, and the phenomenon can be affected or biased by explicit control and manipulation, field and case studies are appropriate. However, it seems clear that qualitative data are used to support the quantitative data analysis.

\section{The Nature of Society/Social World Assumptions}

The functionalist paradigm has drawn upon the sociology of regulation. It concerns an understanding of society in terms of its unity and cohesiveness. The focus of attention is to understand society as an entity. Accordingly, the sociology of regulation is concerned with status quo, social order, consensus, social integration and cohesion, solidarity, need satisfaction, and actuality (Burrell and Morgan 1979). 
Conforming with the functionalist paradigm, mainstream accounting research makes two important assumptions about the nature of society or social world. The first relates to the purposive human behavior. Human beings are assumed to possess a single subordinate goal of utility maximization (Chua 1986; Hunt III and Hogler 1990; Watts and Zimmerman 1986; Sterling 1990; Hines 1989). Thus, people are always seen as rational decision-makers that are economically motivated and self interested.

This can be seen, for instance, within the positive agency theory that views a firm as a set of contracts among factor of production with each factor motivated by its self-interest (Fama 1980). Implicitly, individual utility maximization is viewed as the sole motive for human action and shareholders wealth maximization is used as a basis to measure performance. The performance is considered from a firm's survival perspective or profitability (Neimark and Tinker 1986).

Organizations are coalitions of individual participants which are characterized by rational and cooperative behavior among their members (Caplan 1975; Hopper et al. 1987). Even though only individuals have goals, collectivities may exhibit purposive behavior that implies consensual goals accepted by all members (Chua 1986). An example is the maximization of discounted future cash flows or minimization of transaction costs.

The second assumption constitutes a consequence of the first assumption. Implicit in the purposive individual and organization is the assumption about controllable social order which believes that conflict can always be managed through appropriate accounting systems (Chua 1986). This notion is realized in many forms of accounting tools, such as standard costing systems and divisional performance criteria to avoid conflict (Hopwood 1974).

Within this view, the conflict is perceived as a dysfunction to the consensual or organizational goals. The goals are seen as additive - what is good for the part of the business is also good for the whole. Dysfunction occurs when an individual's or group's interests pass over the organizational goals. It is the task of the accounting researcher to seek specific procedures to correct the dysfunction (Hopwood 1974; Tiessen and Waterhouse 1983; Daft and Macintosh 1978). Most accounting research can be classified within this notion (see, for example: Hopwood 1972; Otley 1978; Brownell 1982; Hirst 1983; Penno 1990).

\section{Mainstream Accounting- Consequences and Limitations}

Several consequences are identified from the dominant assumptions of the mainstream accounting research. First, the belief that reality exists independently of financial accounting and accounting research has brought to the consequence that accounting researchers takes as given and natural the sociopolitical environment. Thus, the sociopolitical process which forms current institutional framework of governments, markets, prices, and business organizations are created independently from accounting and accountants (Hines 1989; Chua 1986; Solomons 1991).

This is reflected in the means-end dichotomy assumptions where the task of accountants is only to provide means for the users with relevant financial information to achieve their goals. The goals of the users are seen as outside the province of accountant. Similarly, concerns about the system of property rights, economic exchange, and the distribution of wealth and 
wealth -creating opportunities are outside the boundary of the accounting field. As stated by Solomons (1991), the job of the accountants is merely to portray certain aspects of society and not to change it since they have no special expertise in that direction.

Scientific accounting as identified with the double-entry system, played an important part in facilitating the rationalistic investment for the purpose of obtaining profits as an essential part of the element in the capitalistic spirit (Sombart as quoted by Yamey 1964). Hence, the concept of capital could only be formulated under the principle of economic rationality introduced by double-entry bookkeeping in its profit concept. This concept made possible the separation of business firm from its owners.

However, Yamey (1964) disagrees and argues that discussion on these matters is unlikely to be fruitful, and these matters, moreover, distract attention from the simple question provoked by the (Sombart's) thesis, namely, the contribution of the double-entry accounting to the solution of problems in business organization and administration. Accordingly, Yamey views accounting as a neutral means that are independent of business practices and their goals.

Accounting is a technology that is not ideologically sterile since it emanates from the social sphere. The accounting framework is a social construction and the technology is framed by ideology. The interpretation of events and even the specification of what constitutes events are functions of the socio-political point of view (Dillard 1991). Thus, by not questioning the extant goals, accounting helps to legitimize extant relations of exchange, production and forms of suppression (Chua 1986; Tinker et al. 1982). Accountants do not simply report facts but he/she has chosen to say something about something (what the accounting report is about) to whom the accounting report is prepared for (Francis 1990).

Second, assumptions of human purpose, rationality, and consensus which are reflected in the consensual goals of utilitymaximization bias to the goals of the capital providers (Chua 1986). This means that accounting practices are geared to provide and sustain a shareholder's view of organizations, in this case, profit maximization (Morgan 1988). It is believed that everyone's interests are ultimately served by the prospering of owners who are treated as synonymous (Hopper et al. 1987). The reason is that workers desire profit maximization because without profit, they could not be paid.

This assumption tends to neglect the complexity of social relations among organizational participants and the social environment outside the organization. For example, accountants and auditors sometimes suggest that they act in public interest. However, it is generally accepted that managerial and external financial reports are intended to protect the rights of investors and creditors. In a more sarcastic statement, Neimark and Tinker (1986) argue that in a capitalist society, it makes no sense at all to say that the goal of the firm is to maximize the janitor's salary.

The single-utility maximization is nothing more than a myth, having no premises and no arguments, except that it is accepted without any questions (Chambers 1980). Because the focus of the functionalist paradigm is the entity or the organization, performance is considered from the organizational perspective. As a result, performance is viewed as non-problematic despite the fact that socio-structure determines the capacity of partici- 
pant groups to impose constraints singled out and identified as the goals of the enterprise (Neimark and Tinker 1986).

In that sense, accounting information is not a product of rational decision making. Rather, it is decisions that need to be rationalized and legitimated for the interest of certain society groups, that is, capital providers (Hines 1989). The profitability and the survival of organizations are not inherently rational, but it must be rationalized to get social legitimacy. Unfortunately, mainstream accounting research has largely neglected this social conflict which exists within the organizational life.

Third, the set of dominant beliefs of scientific research in accounting tends to ignore controversies within the philosophy of social science which have questioned realism and the empirical testability of theories. The scientific method of accounting research as represented by Abdel-Khalik and Ajinkya (1979) constructs a theory based on a verification process from empirical observation. Positive accounting theorists claim that this is the only legitimate accounting research program, even though, in their recent article, Watts and Zimmermann (1990) realize that there are other approaches to accounting research.

Philosophical debates about this issue have been arising among scientific philosophers. Falsificationist, that was popularized by Karl Popper, denies that the truth of scientific claims could be verified. Instead, the falsificationist believes that a proposition can only be falsified (Christenson 1983). According to Mouck (1990), the idea relies on inductive inference which can never be complete in and of itself because it has to be based on limited experience and future experience may contradict it. Thus, the only possible way is to prove the falsify of theories.
However, it has been criticized by Lakatos (1970) on the basis that the falsificationist methodology of science does not fit the actual history of scientific practice. First, tests, under falsificationist methodology must be made in a two-cornered fight between theory and experiment, whereas according to the history of science, tests are at least conducted in a three-cornered fight between rival theories and experiment. Second, under the falsificationist methodology, the only interesting outcome of such confrontation is falsification of theory, whereas in actual practice, the most interesting result is prima facies in confirmation rather than falsification.

Kuhn (1970), on the other hand, argues that the progress of science is through revolutions characterized by competing paradigms. Knowledge is not the result of evolutionary process leading to the accumulation of knowledge. The basic idea is that a theory used for a considerable period of time is rejected by another theory which is inconsistent and completely different with its predecessor. This new theory depicts the phenomena in the natural world more closely than the theory which it supersedes. The history of science follows the process of pre-science, normal science, crisis, revolution, and new normal science.

Unlike Popper, Lakatos, and Kuhn, Feyerabend (1975) claims there is only one principle that can be defended in all circumstances and all stages of human development. That is the principle of anything goes. Lakatos' standards contain no rules in order to tell scientists what they should do. In other words, nothing is ruled out. Based on this reason, his method is classified as irrationalism (Mouck 1990; Casti 1989). 
Except Popper who believes in the notion of realism, Lakatos, Kuhn, and Feyerabend view reality as what the community says it is or relativism, even though their arguments are different (Casti 1989). Unfortunately, mainstream accounting thought does not give enough attention to these philosophical debates. Instead, accounting researchers work within some vogue notion of objective reality or realism and of confronting theory with data (Chua 1986).

Another problem with the mainstream accounting thought is the growing numbers of accounting researchers who question the relevance of the philosophy of the natural science as a basis for accounting research methodology. Accounting which has more affinity to social science is different from the natural science in its basic goals. Social phenomena and social events are constituted by meanings and cultural conventions and vary accordingly (Whitley 1988).

\section{Conclusion and Implication}

\section{Conclusion}

Mainstream accounting that is developed based on the belief of physical realism has been changing gradually from extreme realism to contextual field of reality. This change has shifted the emphasis of research from an empirical analysis of concrete structural relationship to a large model of interconnections between environments and the organization being studied. However, the three approaches still share the same ontology of physical realism which believes that the reality exists independently of accounting and accounting research. Consequently, accountant takes as given and natural the sociopolitical processes which form insti- tutional frameworks where accounting is seen as an ideologically sterile technology.

This belief gives way to the adoption of positivism which states that accounting research must separate observation and theoretical constructs as has been done in natural sciences. Accordingly, a research methodology relies upon hypothetico-deductive approach dominates scientific research in accounting, nowadays. Unfortunately, the dominant belief of the approach tends to ignore the controversies within the philosophy of social sciences about realism and empirical testability of theories.

An assumption that people posses a single goal of utility-maximization tends to neglect the complexity of social relations among people within an organization and social environment outside the organization. It is believed that the consensual goal of utility-maximization biases to the goals of investors and stockholders. Implicit to this assumption is the belief that conflict can always be managed through appropriate accounting systems. This condition will give birth to the fact that the objectivity of accounting information is a controversial issue and needs to be reviewed.

\section{Implication}

The differences of social science from the natural science are due to the complexity of social facts. These facts, according to Cohen (1953) are connected to their less repeatable characters, their less direct observability, their greater variability and lesser uniformity, and their greater difficulty of isolating one factor at a time. These phases are so dependent of one another that we shall not treat them separately. 
Walbydi-MainstreamAccountingandItsParadigm

Accounting as a social science has different characteristics with the natural sciences. Accordingly, efforts to adopt and imitate the methodology of natural sciences by using systematic protocol and technique of research in accounting re- search and accounting theorizing will not produce any answer to the accounting problems. Thus accounting researchers need to develop research methodologies that fit to the characteristics of accounting phenomena as social phenomena.

\section{References}

Abdel-khalik, A. R., and B. P. Ajinkya. 1979. Empirical Research in Acounting-A Methodological Viewpoint. Sarasota Florida: American Accounting Association.

1983. An evaluation of the everyday accountant and researching his reality. Accounting Organizations and Society (8/4): 375-384.

Ansari, S. L. 1977. An integrated approach to control system design. Accounting Organizations and Society (2/2): 101-112.

Belkaoui, A. 1987. Inquiry and Accounting-Alternative Methods and Presearch Perspectives. Westport Connecticut: Greenwood Press Inc.

Brownell, P. 1981. Participation in budgeting, locus of control and organizational effectiveness. The Accounting Review (October): 844-860.

1982. The role of accounting data in performance evaluation, budgetary participation, and organizational effectiveness. Journal of Accounting Research 20/1 ( Spring): 13-27.

Burchell, S. et al. 1980. The role of accounting in organizationa and society. Accounting Organizations and Society (5/1): 5-27.

Burrell, G., and G. Morgan. 1979. Sociological Paradigms and Organizational Analysis. London: Heinemann Educational Books Ltd..

Caplan, E. H. 1975. Behavioral assumptions of management accounting. in Alfred Rappaport (ed). Information for Decision Making-Quantitative and Behavioral Dimensions. 2 ed. Englewood Cliffs (NJ): Prentice Hall Inc.: 352-366.

Casti, J. L. 1989. Paradigms Lost-Images of Man in the Mirror of Science. New York: William Morrow and Company Inc.

Chambers, R. J. 1980. The myths and the science of accounting. Accounting Organizations and Society (5/1): 167-180.

Christenson, C. 1983. The methodology of positive accounting. The Accounting Review (January): 1-22.

Chua, W. F. 1986. Radical development in accounting thought. The Accounting Review (October): 601-632. 
Cohen, M. R. 1953. Reason in social science. in Herbert Feigl and May Brodbeck (editors). Readings in the Philosophy of Science. New York: Appleton-CenturyCrofts Inc.

Covaleski, M. A., and M. W. Dirsmith. 1990. Dialectic tension, double reflexivity and the everyday accounting researcher: On using qualitative Methods. Accounting Organizations and Society (15/6): 543-573.

Daft, R. L., and N. B. Macintosh. 1978. A new approach to design and use of management accounting. California Management Review XXI/1 (Fall): 82-92.

Dermer, J. 1988. Control and organizational order. Accounting Organizations and Society (13/1): 25-36.

Dillard, J. F. 1991. Accounting as a critical social science. Accounting Auditing \& Accountability Journal (4/1): 8-28.

Eisenhardt, K. M. 1989. Building theories from case study research. Academy of Management Review (14/4): 532-550.

Fama, E. F. 1980. Agency problems and the theory of the firm. Journal of Political Economy 88/2 (April): 289-307.

Feyerabend, P. 1975. Against Method. London: Verso Editions.

Francis, J. R. 1990. After virtue? accounting as a moral and discursive practice. Accounting Auditing and Accountability Journal (3/3): 5-17.

Gaffikin, M. J. R. 1984. Scientific theory construction in accounting. in M.J.R. Gaffikin (ed). Contemporary Accounting Thought. Sydney: Prentice Hall of Australia Pty. Ltd. : 7-27.

Hagg, I., and G. Hedlund. 1979. Case studies. in Accounting Research ( Accounting Organizations and Society 4/1-2): 135-143.

Hines, R. D. 1989. The sociopolitical paradigm in financial accounting research. Accounting Auditing and Accountability Journal (2/2): 53-76.

Hirst, M. 1983. Reliance on accounting measures, task uncertainty, and dysfunctional behavior: Some extensions. Journal of Accounting Research 21/2 (Autumn): 596604.

Hopper, T., and A. Powell. 1985. Making sense of research into the organizational and social aspects of management accounting: A review of its underlying assumptions. Journal of Management Studies (September): 429-465.

Hopper, T. et al. 1987. Accounting for accounting: Towards the development of a dialectical view. Accounting Organizations and Society (12/5): 437-456.

Hopwood, A. G. 1983. On trying to study accounting in the contexts in which it operates. Accounting Organizations and Society (8/2-3): 287-305. 
Walyudi-MainstreamAccountingandItsParadigm

Hopwood, A. G. 1972. An empirical study of the role of accounting data in performance evaluation. Supplement to Journal of Accounting Research (10): 156-182.

1974. Accounting and Human Behaviour. Englewood Cliffs (New Yersey): Prentice Hall Inc.

1987. The archaeology of accounting systems. Accounting Organizations and Society (12/3): 207-234.

Hunt III, H. G., and R. L. Hogler. 1990. Agency theory as ideology: A comparative analysis based on critical legal theory and radical accounting. Accounting Organizations and Society (15/5): 437-455.

Kaplan, R. S. 1986. The role for empirical research in management accounting. Accounting Organizations and Society (11/4-5): 429-452.

Kuhn, T. S. 1970. The Structure of Scientific Revolutions. 2nd ed. Chicago: The University of Chicago Press Ltd.

Imre. 1970. Falsification and the methodology of scientific research programmes. in Imre Lakatos and Alan Musgrave (editors). Criticism and the Growth of Knowledge. London: Cambridge University Press: 91-196.

Morgan, G. 1988. Accounting as reality construction: Towards a new epistemology for accounting practice. Accounting Organizations and Society (13/5): 477-485.

Morgan, G., and L. Smircich. 1980. The case for qualitative research. Academy of Management Review (5/4): 491-500.

Mouck, T. 1990. Positive accounting theory as a lakatosian research programme. Accounting Business Research (20/79): 231-239.

Neimark, M., and T. Tinker. 1986. The social construction of management control systems. Accounting Organizations and Society (11/4-5): 369-395.

Otley, D. T. 1978. Budget use and managerial performance. Journal of Accounting Research 16/1 (Spring): 122-149.

Penno, M. 1990. Accounting systems, participation in budgeting, and performance evaluation. The Accounting Review (April): 303-314.

Richards, S. 1883. Philosophy and Sociology of Science. Oxford: Basil Blackwell Publisher Ltd.

Smith, C. et al. 1988. Case study research in accounting: Methodological breakthrough or ideological weapon.? Advances in Public Interest Accounting (2): 95-120.

Solomons, D. 1991. Accounting and social change: A neutralist view. Accounting Organizations and Society (16/3): 287-295.

Steffy, B. D., and A. J. Grimes. 1986. A critical theory of organization science. Academy of Management Review (11/2): 322-336.

Sterling, R. R. 1990. Positive accounting: An assessment. ABACUS (26/2): 97-135. 
Stockman, N. 1983. Antipositivist Theories of the Sciences. Dordrecht: D Reidel Publishing Company.

Tiessen, P., and J. H. Waterhouse. 1983. Towards a descriptive theory of management accounting. Accounting Organizations and Society (8/2-3): 251-267.

Tinker, A. M. et al. 1982. The normative origins of positive theories: Ideology and accounting thought. Accounting Organizations and Society (7/2):167-200.

Tinker, A. M. et al. 1991. Falling dawn the hole in the middle of the road: Political quietism in corporate social reporting. Accounting Auditing and Accountability Journal (4/2): 28-54.

Tomkins, C., and R. Groves. 1983. The everyday accountant and researching his reality. Accounting Organizations and Society (8/4): 361-374.

Waterhouse, J. H., and P. Tiessen. 1978. A contingency framework for management accounting systems research. Accounting Organizations and Society (3/1): 65-76.

Watts, R. L., and J. L. Zimmerman. 1990. Positive accounting theory: A ten year perspective. The Accounting Review (January): 131-156.

Hall Inc.

1986. Positive Accounting Theory. Englewood Cliffs (N.J.): Prentice

Whitley, R. D. 1988. The possibility and utility of positive accounting theory. Accounting Organizations and Society (13/6): 631-645.

Wisdom, J. O. 1987. Philosophy of the Social Science I: A Methascientific Introduction. Aldershot: Growing Publishing Company Ltd.

Yamey, B. S. 1964. Accounting and the rise of capitalism: Further notes on a theme by Sombart. Journal of Accounting Research (Autumn): 117-136.

Yin, R. K. 1984. Case study research design and methods. Applied Social Research Methods Series 5. Beverly Hill: Sage Publications. 
Walyudi-MainstreamAccountingandItsParadigm

DAFTAR RIWAYAT HIDUP:

Nama: $\quad$ Drs. Imam Wahyudi, Ak., M.Com.(Honours)

Alamat: Harapan Baru Regency B3/38 Bekasi Barat

Telp. 525-2533 (Kantor), 480-1578 (Rumah), 0816-719624 (Handphone)

Pendidikan: $\quad$ Sarjana Ekonomi Jurusan Akuntansi UGM 1984 (lulus) Master of Commerce in Accounting (Honours) The University of Wollongong Australia 1991 (lulus)

Pekerjaan: $\quad$ Ketua Program Magister Manajemen STIE Perbanas Jakarta Konsultan manajemen dan akuntansi 